\title{
Kualitas Pelayanan Jasa Pada Usaha Laundry Ririn Di Jalan G. Obos XII Kota Palangka Raya
}

\author{
R. Susanti, Tonich, R. Alexandro \\ Program Studi Pendidikan Ekonomi \\ Fakultas Keguruan dan Ilmu Pendidikan \\ Universitas Palangka Raya \\ Kampus UPR Tunjung Nyaho Jalan Hendrik, Indonesia \\ (Diterima 15-09-2019; Disetujui 14-11-2019)
}

\begin{abstract}
ABSTRAK
Kualitas pelayanan sangat penting pada industri jasa, kualitas pelayanan terbaik merupakan suatu profit strategi untuk meningkatkan lebih banyak pelanggan baru, mempertahankan pelanggan yang ada, menghindari kaburnya pelanggan, dan menciptakan keunggulan khusus yang tidak ada hanya bersaing dari segi harga. Apabila pelayanan yang diterima atau dirasa sesuai dengan yang diharapkan oleh pelanggan, maka kualitas pelayanan dapat dipersepsikan baik dan memuaskan. Keberhasilan suatu perusahaan sangat dipengaruhi oleh bagaimana perusahaan tersebut memberi kepuasan dan kebahagian kepada pelanggan. Perusahaan sebagai individu dalam suatu sistem memfokuskan kegiatan kepada pelanggan sebagai konsumen jasa, agar dapat lebih efektif dan efisien dalam menjalankan kegiatan dalam memberikan atau menyediakan jasa maupun produk yang berkualitas sesuai dengan harapan pelanggan. Dilain pihak, perusahaan sebagai suatu sistem juga harus membahagiakan pelanggan internal, dalam hal ini adalah karyawan (produsen jasa). Tujuannya agar dapat menghasilkan layanan yang berkualitas sesuai dengan harapan pelanggan eksternal.

Dari lima dimensi kualitas pelayanan yang digunakan untuk melihat kualitas pelayanan jasa pada laundry Ririn di jalan G. Obos XII Palangka Raya yaitu Tangibel (Berwujud), Reliability (Kehandalan), Responsiviness (Ketanggapan), Assurance (Jaminan), dan Empathy (Empati) dapat disimpulkan bahwa kualitas pelayanan jasa yang ada di laundry Ririn Palangka Raya sangat baik. Ini bisa dilihat dari hasil wawancara yang dilakukan peneliti kepada para informan. Dan laundry Ririn Palangka Raya selalu meningkatkan kualitas guna menciptakan hubungan yang saling menguntungkan bagi para pelanggan dan pemberi pelayanan secara terus-menerus.
\end{abstract}

Kata Kunci: Kualitas Pelayanan Jasa

\section{PENDAHULUAN}

Saat ini perusahaan jasa berada pada lingkungan bisnis yang semakin sengit dengan adanya globalisasi. Perusahaan yang mempunyai kualitas yang baik akan merubah perilaku konsumen sehingga mempengaruhi kepuasan konsumen karena perusahaan yang memberikan produk atau jasa berkualitas dan bermutu, serta dapat memenuhi tingkat kepentingan konsumen akan dapat lebih bertahan karena menciptakan nilai yang lebih unggul dari pesaingnya, sehingga perusahaan baru yang baru ingin masuk ke lingkungan pasar harus mendalami lagi perilaku konsumen yang terus berkembang.

Salah satu usaha untuk menarik konsumen pengguna jasa yaitu dengan memberikan kualitas pelayanan yang dapat menciptakan kepuasan setelah menggunakan jasa tersebut. Menurut McDougall dan Levesque (2000), bahwa kepuasan pelanggan pada jasa dipengaruhi oleh dua 
variabel, yaitu kualitas inti dan kualitas peripheral. Kualitas inti merupakan penilaian konsumen terhadap kualitas layanan, keramahan layanan, ketepatan layanan, dan ketepatan informasi yang dibutuhkan konsumen. Kualitas peripheral merupakan penilaian konsumen terhadap suatu kualitas yang menyebakan suatu barang atau jasa menjadi pilihan dan menjadi kualitas pendukung, seperti: lokasi, fasilitas.

Kualitas pelayanan sangat penting pada industri jasa, kualitas pelayanan terbaik merupakan suatu profit strategi untuk meningkatkan lebih banyak pelanggan baru, mempertahankan pelanggan yang ada, menghindari kaburnya pelanggan, dan menciptakan keunggulan khusus yang tidak ada hanya bersaing dari segi harga. Apabila pelayanan yang diterima atau dirasa sesuai dengan yang diharapkan oleh pelanggan, maka kualitas pelayanan dapat dipersepsikan baik dan memuaskan.

Keberhasilan suatu perusahaan sangat dipengaruhi oleh bagaimana perusahaan tersebut memberi kepuasan dan kebahagian kepada pelanggan. Perusahaan sebagai individu dalam suatu system memfokuskan kegiatan kepada pelanggan sebagai konsumen jasa, agar dapat lebih efektif dan efisien dalam menjalankan kegiatan dalam memberikan atau menyediakan jasa maupun produk yang berkualitas sesuai dengan harapan pelanggan. Dilain pihak, perusahaan sebagai suatu sistem juga harus membahagiakan pelanggan internal, dalam hal ini adalah karyawan (produsen jasa). Tujuannya agar dapat menghasilkan layanan yang berkualitas sesuai dengan harapan pelanggan eksternal.

Usaha di bidang jasa pada saat ini berkembang dengan sangat pesat terutama jasa laundry dan perawatan, karena para pelaku bisnis dibidang jasa ini melihat bahwa pangsa pasar pada sector jasa akan bertahan lebih lama jika dibandingkan dengan industri manufaktur. Dengan semakin banyaknya pesaing dalam bisnis sejenis, pelanggan mempunyai banyak pilihan dalam menggunakan jasa laundry dan perawatan tersebut. Hal tersebut menciptakan iklim persaingan yang semakin ketat, sehingga membuat para pelaku bisnis diharuskan untuk memiliki keunggulan dalam bersaing selain hal tersebut, perusahaan yang bergerak di bidang jasa laundry dan perawatan harus dapat menjalankan konsep pemasaran yang tepat, salah satunya adalah memberikan pelayanan yang terbaik dan berkualitas sesuai dengan harapan pelanggan bahkan melebihi harapan pelanggan sehingga dapat memberikan kepuasan maksimal kepada pelanggan, karena kepuasan pelanggan merupakan faktor penting yang dapat membentuk kesetiaan atau loyalitas pelanggan.

Fasilitas yang ditawarkan oleh perusahaan juga mempunyai pengaruh yang besar terhadap kepuasan konsumen, yang berarti bahwa semakin lengkap fasilitas yang disediakan dan didukung oleh desain yang menarik maka semakin banyak pula konsumen yang tertarik sehingga memutuskan untuk menggunakan jasa pada perusahaan tersebut, karena jika fasilitas yang diberikan lengkap dan menarik maka permintaan akan jasa juga akan meningkat yang berarti akan mempengaruhi konsumen dalam memilih perusahaan jasa yang ditawarkan sebagai tempat membeli/menggunakan jasa dan dengan sendirinya akan tertanam dibenak pelanggan akan kualitas jasa pada perusahaan tersebut. Menurut Drajat (2009) Fasilitas adalah segala sesuatu yang merupakan sarana pokok dan penunjang kemudahan dan kenyamanan yang secara sengaja yang disediakan oleh pihak perusahaan untuk digunakan, dimanfaatkan ataupun dinikmati oleh konsumen di tempat penjualan jasa.

Kebutuhan ekonomi masyarakat yang semakin tinggi menuntut masyarakat untuk meningkatkan pendapatannya, sehingga mau tidak mau masyarakat dituntut untuk lebih efisien dalam memanfaatkan waktu ataupun jam kerjanya. Situasi dan kondisi kesibukan masyarakat kota Palangka Raya yang terus meningkat sebagai upaya pemenuhan kebutuhan hidup menyebabkan mereka tidak sempat lagi menyelesaikan pekerjaan domestik terutama mencuci dan menyetrika pakaian, sebagian masyarakat beranggapan bahwa mencuci dan menyetrika banyak memakan waktu, dengan pertimbangan opportunity cost maka mereka menggunakan jasa laundry. Hal inilah memberika peluang jasa laundry untuk berkembang. Aspek lain yang menjadi pertimbangan 
masyarakat untuk menggunakan jasa laundry ini adalah kondisi air sebagian kota Palangka Raya memiliki bau yang tidak sedap dan berwarna sehingga dapat merusak pakaian atau kain yang dicuci pada air sersebut.

Disamping itu, pelaku usaha jasa laundry Ririn di jalan g.obos Palangka Raya menggunakan mesin cuci berkualitas tinggi sehingga tidak merusak pakaian yang dicuci, selain itu laudry juga menggunakan obat-obatan khusus untuk merawat pakaian sehingga warna dari pakaian tersebut tetap terpelihara dan wangi. Waktu yang dibutuhkan pihak laundry Ririn di jalan g.obos Palangka Raya untuk menyelesaikan pakaian konsumen juga tidak lama, hanya dalam dua hari pakaian konsumen sudah dikemas dalam keadaan bersih, rapi dan wangi. Hal ini menyebabkan masyarakat cenderung memilih jasa laundry dari pada menyewa pekerja lepas untuk mencuci dan menyetrika pakaian mereka, karena dengan menggunakan jasa laundry hasil yang diperoleh lebih baik dan bila dilihat dari segi biaya yang dikeluarkan perbedaannya sangat sedikit. Apalagi saat ini beberapa laundry melengkapi fasilitasnya dengan fasilitas antar jemput, pihak laundry Ririn di jalan g.obos Palangka Raya akan menjemput pakaian kotor yang akan dicuci dan mengantar kembali pakaian yang sudah selesai dikerjakan ke alamat konsumen. Hendri Parulian, 2013, Skripsi, Judul: Persepsi Konsumen Terhadap Kualitas Layanan Jasa Penyewaan Lapangan Futsal. Hasil Penelitian dalam penelitian ini kualitas layanan pada jasa penyewaan lapangan futsal dilihat dari lima dimensi kualitas layanan yaitu: a) bukti fisik, b) kehandalan, c) daya tanggap, d) jaminan, e) empati. Kesimpulan yang didapat, maka secara umum penerapan kualitas layanan di bidang jasa penyediaan lapangan futsal, terutama di kota Bengkulu sudah masuk dalam kategori baik dengan skor rata-rata dari lima dimensi kualitas layanan 3,54. Dari kelima dimensi kualitas layanan jasa di lapangan futsal kota Bengkulu diuraikan sebagai berikut, yaitu pada dimensi bukti fisik dengan penilaian kategori baik, yaitu dengan skor rata-rata sebesar 3,84. Pada dimensi kehandalan masuk dalam kategori baik dengan skor rata-rata sebesar 3,67. Dimensi daya tanggap masuk dalam kategori baik dengan skor rata-rata 3,41. Dimensi jaminan masuk dalam kategori cukup baik dengan skor 3,38. Dan pada dimensi terakhir yaitu dimensi empati masuk dalam kategori baik dengan skor rata-rata 3,40.

\section{METODE PENELITIAN}

Pada penelitian ini penulis menggunakan pendekatan penelitian yaitu dengan pendekatan kualitatif, dengan metode fenomenologi yang mencoba menjelaskan atau mengungkap makna konsep atau fenomena pengalaman yang didasari oleh kesadaran yang terjadi pada beberapa individuini digunakan agar mendapatkan data yang mendalam, Dalam penelitian ini penulis berperan ganda, yaitu selain sebagai pengumpul data juga sebagai instrumen, yaitu untuk mendapatkan data lebih akurat dari pemilik, karyawan dan konsumen tentang Kualitas Pelayanan Jasa Laundry Ririn di Jalan G. Obos XII PalangkaRaya.

Sumber data dalam penelitian adalah subjek darimana data diperoleh. Sumber data utama dalam "Penelitian kualitatif ialah kata-kata dan tindakan selebihnya adalah data tambahan seperti dokumen dan lain-lain" (Basrowi dan Suwandi, 2008:169). Berkaitan dengan hal itu, pada bagian ini jenis data dibagi kedalam kata-kata, tindakan, sumber data tertulis, dan foto. Dimana data hasil penelitian didapatkan melalui dua sumber yaitu data primer dan data sekunder.

Untuk mengungkapkan data mengenai bagaimana persepsi konsumen terhadap kualitas layanan jasa laundry Ririn Palangka Raya dilihat dari dimensi Tangibles (bukti fisik), Reliability (Kehandalan), Responsiveness (Daya Tanggap), Assurance (jaminan) dan Emphaty (Empati) Palangka Raya, maka penulis menggunakan teknik pengumpulan data sebagai berikut: observasi, wawancara, dan dokumentasi.

Analisis data dalam penelitian kualitatif dilakuka pada saat pengumpulan data berlangsung, dan setelah selesai pengumpulan data dalam periode tertentu, aktivitas dalam analisis data kualitatif 
yaitu: reduksi data, penyajian data, dan menarik kesimpulan. Analisis Selama Di Lapangan Model Miles And Huberman Dalam

\section{Tahap-Tahap Penelitian}

Adapun tahap-tahap yang dilakukan dalam penelitian ini adalah:

\section{Tahap Pendahuluan}

Sebelum penulis melakukan penelitian, penulis membuat surat izin observasi terlebih dahulu ke pihak fakultas keguruan dan ilmu pendidikan Universitas Palangka Raya. Kemudian mendatangi lokasi penelitian, penulis terjun langsung ke lapangan yaitu di Jasa Laundry Ririn di Palangka Raya agar lebih mudah untuk melakukan penelitian. Setelah itu menyusun proposal penelitian, sebelum proposal ini di buat terlebih dahulu melakukan studi pendahuluan ke lokasi penelitian, dan merumuskan permasalahan yang ada.

2. Tahap Pelaksanaan penelitian

Pengumpulan data pada tahap ini yang dilakukan peneliti dalam mengumpulkan data.

3. Tahap Akhir Penelitian adalah analisis data yaitu : Menyajikan data dalam bentuk deskripsi, menganalisa data sesuai dengan tujuan yang ingin dicapai.

\section{HASIL DAN PEMBAHASAN}

Ada beberapa tawaran pelayanan jasa laundry yang di tawarkan oleh Ririn laundry yaitu: Tabel 1. Data Jasa Layanan Laundry

\begin{tabular}{cll}
\hline No. & & Jenis Layanan Laundry \\
\hline 1. & Pakaian & \\
2. & Gorden \\
3. & Karpet & \\
4. & Tas & \\
5. & Boneka & \\
6. & Sepatu & \\
\hline
\end{tabular}

Adapun tenaga kerja yang membantu dalam pelayanan jasa laundry adalah sebagai berikut: Tabel 2. Tenaga Kerja

\begin{tabular}{ccc}
\hline No. & Nama & Jumlah \\
\hline 1. & Pemilik & 1 \\
2. & Karyawan & 2 \\
\hline
\end{tabular}

Adapun peralatan yang dipakai oleh tenaga kerja dalam melakukan kegiatan mencuci adalah:

Tabel 3. Data Peralatan

\begin{tabular}{ccc}
\hline No. & Nama & Jumlah \\
\hline 1. & Mesin Cuci Kapasitas $12 \mathrm{~kg}$ & 1 \\
2. & Mesin Cuci Kapasitas $7 \mathrm{~kg}$ & 3 \\
3. & Mesin Pengering $12 \mathrm{~kg}$ & 3 \\
4. & Setrika & 4 \\
5. & Vacuum Table & 1 \\
\hline
\end{tabular}

Sumber Data: Laundry Ririn 2019

Setelah peneliti melakukan penelitian di Ririn Laundry jalan G. Obos XII Palangka Raya dengan metode wawancara, observasi dan dokumentasi, dapat dipaparkan hasil penelitian sebagai berikut: Bagaimanakah kualitas layanan jasa laundry Ririn di jalan g.obos xii Kota Palangka Raya? Menurut Kotler (2007) kualitas pelayanan harus dimulai dari kebutuhan pelanggan dan berakhir pada persepsi pelanggan, dimana persepsi pelanggan terhadap kualitas pelayanan merupakan 
penilaian menyeluruh atas keunggulan suatu pelayanan. Menurut (Parasuraman, et al, 1988), terdapat lima indikator SERVQUAL sebagai berikut:

a. Keandalan (reliability), yaitu kemampuan perusahaan untuk memberikan pelayanan sesuai yang dijanjikan secara akurat dan terpercaya. Kinerja harus sesuai dengan harapan pelanggan yang berarti ketepatan waktu, pelayanan yang sama untuk semua pelanggan tanpa kesalahan, sikap yang simpatik, dan dengan akurasi yang tinggi.

Hal ini sesuai dengan hasil wawancara peneliti dengan Ibu Ririn selaku pemilik dari usaha Laundry Ririn yang dilakukan pada hari Jum'at, 12 Juli 2019. Peneliti menanyakan masalah ketepatan waktu (akurat dan terpercaya) dalam hal mengerjakan cucian. Berdasarkan hasil wawancara, dapat ditarik kesimpulan bahwa kualitas jasa pelayanan yang diberikan Laundry Ririn pada dimensi Keandalan (reliability) terutama ketapatan waktu (akurat dan terpercaya) sangat memuaskan pelanggan, meskipun ada hambatan dilapangan seperti kendala pemadaman listrik, tapi semua bisa diatasi oleh laundry Ririn, sehingga bisa tepat waktu memberikan layanan kepada pelanggan yang menggunakan jasa usaha laundry ririn.

b. Ketanggapan (responsiveness), yaitu suatu kemampuan untuk membantu dan memberikan pelayanan yang cepat (responsif) dan tepat kepada pelanggan, dengan penyampaian informasi yang jelas. Berdasarkan hasil wawancara peneliti dengan ibu Ririn selaku pemilik usaha jasa Laundry Ririn mengenai pelayanan yang cepat/respon kepada pelanggan, Berdasarkan hasil wawancara dapat ditarik kesimpulan bahwa kualitas jasa pelayanan yang diberikan Laundry Ririn pada dimensi ketanggapan (responsiveness), yaitu suatu kemampuan untuk membantu dan memberikan pelayanan yang cepat (responsif) dan tepat kepada pelanggan, dengan penyampaian informasi yang jelas. Semuanya sudah dijalankan oleh Laundry Ririn, dan pelanggan merasa dilayani.

c. Jaminan (assurance), yaitu pengetahuan, kesopansantunan, dan kemampuan para pegawai perusahaan untuk menumbuhkan rasa percaya para pelanggan kepada perusahaan. Dari hasil wawancara dapat diambil kesimpulan, bahwa manajemen laundry Ririn sangat bertanggung jawab dan bisa memberikan layanan yang memuaskan kepada pelanggan, dan pelanggan pun merasakan kualitas layanan yang diberikan laundry Ririn.

d. Empati (empathy), yaitu memberikan perhatian yang tulus dan bersifat individual atau pribadi yang diberikan kepada para pelanggan dengan berupaya memahami keinginan konsumen. Kesediaan dalam memberikan perhatian yang mendalam dan khusus kepada masing-masing pelanggan, variabel-variabel: 1) perhatian secara individu kepada pelanggan. 2) memperhatikan kebutuhan dan keperluan pelanggan. Peneliti menanayakan bagaimana sikap karyawan laundry Ririn Palangka Raya, ketika melihat konsumen yang datang. Dari hasil wawancara, dapat di tarik kesimpulan bahwa dimensi empati yang dilakukan oleh laundry Ririn sudah dilakukan. Pelanggan semua merasa dilayani oleh laundry Ririn.

e. Bukti fisik (tangibles), yaitu kemampuan suatu perusahaan dalam menunjukkan eksistensinya kepada pihak eksternal. Yang meliputi fasilitas fisik (gedung, gudang, dan lain sebagainya), perlengkapan dan peralatan yang dipergunakan (teknologi), serta penampilan pegawainya. Dalam hal bukti fisik seperti peralatan yang digunakan oleh laundry Ririn sangat memadai, ini sudah terlihat bagaimana laundry Ririn melayani para pelanggannya dengan baik. Dan peneliti melakukan wawancara bagaimana dengan fasilitas peralatan yang ada di laundry Ririn, seperti hasil wawancara peneliti yang dilakukan pada hari Jumat 12 Juli 2019 dengan Ibu Ririn selaku pemilik usaha jasa laundry. Dari hasil wawancara di atas, dapat ditarik kesimpulan bahwa dimensi tangible 
yang dimiliki oleh jasa laundry Ririn sangat memadai, berdasarkan wawancara peneliti dengan pemilik, karyawan dan pelanggan.

Hasil dan analisis kualitatif terhadap masing-masing dimensi kualitas pelayanan dapat diuraikan dengan penjelasan sebagai berikut:

\section{Reliability}

Jasa layanan laundry Ririn yang beralamat di jalan G. Obos XII Palangka Raya, sudah melaksanakan reliability (keandalan) yaitu kemampuan untuk menyediakan pelayanan yang terpercaya dan akurat kepada para pelanggan yang datang ke laundry Ririn. Kinerja harus sesuai dengan harapan pelanggan tanpa kesalahan. Kemampuan untuk melaksanakan jasa yang dijanjikan dengan terpercaya dan akurat. Hal ini berarti tingkat kehandalan di mata pelanggan, meliputi kemampuan memberikan layanan yang dijanjikan dengan segera, akurat, dan memuaskan, yang meliputi catatan transaksi yang lengkap, kredibilitas/bonafiditas/citra perusahaan dan daya tarik keunggulan kualitas pelayanan. Dan semua ini dilakukan agar kualitas pelayanan kepada para pelanggan laundry Ririn Palangka Raya dapat dipertahankan dan selalu dipercaya oleh pelanggan yang menggunakan jasa laundry.

2. Responsiveness

Bagaimana memberikan layanan yang cepat dan menangani masalah atau komplain dengan baik. Sebuah istilah lain yang sering kita dengar adalah tanggap terhadap kebutuhan pelanggan. Sebagaimana sifat manusia yang pada umumnya senang apabila diperhatikan, dilayani dengan cepat dan dibantu pada saat mengalami masalah. Keluhan atau complain yang dilakukan oleh para pelanggan kami yang menggunakan jasa laundry Ririn Palangka Raya cepat kami tanggapin dan di atasi, jasa layanan laundry Ririn sangat memperhatikan kualitas pelayanan yang diberikan kepada para pelanggan dan jasa laundry Ririn Palangka Raya. Sehingga apabila dalam keadaan tertentu menghadapi ketidak nyamanan maka akan dengan cepat bereaksi karena merasa tidak puas. Jadi responsiveness atau tanggap terhadap kebutuhan pelanggan adalah factor yang sangat penting dalam melayani pelanggan.

3. Assurance (Jaminan)

Setiap bentuk pelayanan memerlukan adanya kepastian atas pelayanan yang diberikan. Bentuk kepastian dari suatu pelayanan sangat ditentukan oleh jaminan dari pegawai yang memberikan pelayanan, sehingga orang yang menerima pelayanan merasa puas dan yakin bahwa segala bentuk urusan pelayanan yang dilakukan atas tuntas dan selesai sesuai dengan kecepatan, ketepatan, kemudahan, kelancaran dan kualitas layanan yang diberikan. Jasa laundry Ririn Palangka Raya telah memberi jaminan atas pelayanan yang diberikan oleh karyawan sangat ditentukan oleh performance atau kinerja pelayanan, sehingga diyakini bahwa karyawan tersebut mampu memberikan pelayanan yang handal kepada para pelanggan, mandiri dan profesional yang berdampak pada kepuasan pelayanan yang diterima.

4. Emphaty (empati/perhatian)

Jasa laundry Ririn telah memberikan perhatian yang tulus dan bersifat individual atau pribadi yang diberikan kepada para pelanggan dengan berupaya memahami keinginan konsumen. Dimana suatu perusahaan diharapkan memiliki pengertian dan pengetahuan tentang pelanggan, memahami kebutuhan pelanggan secara spesifik, serta memiliki waktu pengoprasian yang nyaman bagi pelanggan. Laundry Ririn Palangka Raya yang beralamat di jalan G. Obos XII Palangka Raya memahami masalah para pelanggannya dan bertindak demi kepentingan pelanggan, serta memberikan personal kepada para pelanggan dan memiliki jam operasi yang nyaman. Setiap kegiatan atau aktivitas pelayanan memerlukan adanya pemahaman dan pengertian dalam kebersamaan asumsi atau kepentingan terhadap suatu hal yang berkaitan dengan pelayanan. Pelayanan akan berjalan dengan lancar dan berkualitas 
apabila setiap pihak yang berkepentingan dengan pelayanan memiliki adanya rasa empati atau perhatian (empathy) dalam menyelesaikan atau mengurus atau memiliki komitmen yang sama terhadap pelayanan.

5. Tangibles

Jasa laundry Ririn dalam memberikan pelayanan merupakan bukti nyata yang diberikan oleh pemberi jasa kepada para konsumen/pelanggan. Setiap orang yang menginginkan pelayanan dapat merasakan pentingnya bukti fisik yang ditunjukkan oleh pengembang pelayanan, sehingga pelayanan yang diberikan memberikan kepuasan. Bentuk pelayanan bukti fisik biasanya berupa sarana dan prasarana pelayanan yang tersedia, teknologi pelayanan yang digunakan, performance pemberi pelayanan yang sesuai dengan karakteristik pelayanan yang diberikan dalam menunjukkan prestasi kerja yang dapat diberikan dalam bentuk pelayanan fisik yang dapat dilihat.

Tidak dapat dipungkiri bahwa dalam suatu organisasi modern dan maju, pertimbangan dari para pengembang pelayanan, senantiasa mengutamakan bentuk kualitas kondisi fisik yang dapat memberikan apresiasi terhadap orang yang memberi pelayanan. Kualitas pelayanan berupa kondisi fisik merupakan bentuk kualitas pelayanan nyata yang memberikan adanya apresiasi dan membentuk imej positif bagi setiap individu yang dilayaninya dan menjadi suatu penilaian dalam menentukan kemampuan dari pengembang pelayanan tersebut memanfaatkan segala kemampuannya untuk dilihat secara fisik, baik dalam menggunakan alat dan perlengkapan pelayanan, kemampuan menginovasi dan mengadopsi teknologi, dan menunjukkan suatu performance tampilan yang cakap, berwibawa dan memiliki integritas yang tinggi sebagai suatu wujud dari prestasi kerja yang ditunjukkan kepada orang yang mendapat pelayanan.

\section{Kesimpulan}

\section{KESIMPULAN DAN SARAN}

Dari lima dimensi kualitas pelayanan yang digunakan untuk melihat kualitas pelayanan jasa pada laundry Ririn di jalan G. Obos XII Palangka Raya yaitu Tangibel (Berwujud), Reliability (Kehandalan), Responsiviness (Ketanggapan), Assurance (Jaminan), dan Empathy (Empati) dapat disimpulkan bahwa kualitas pelayanan jasa yang ada di laundry Ririn Palangka Raya sangat baik. Ini bisa dilihat dari hasil wawancara yang dilakukan peneliti kepada para informan. Dan laundry Ririn Palangka Raya selalu meningkatkan kualitas guna menciptakan hubungan yang saling menguntungkan bagi para pelanggan dan pemberi pelayanan secara terus-menerus.

\section{Saran}

Dari hasil penelitian dan kesimpulan yang ada, dengam melihat kualitas pelayanan jasa laundry Ririn kedepan, maka peneliti dapat mengemukan saran-saran sebagai berikut:

1. Laundry Ririn Palangka Raya diharapkan bisa meningkatkan kualitas pelayanan kepada masyarakat khususnya pada para pelanggan jasa laundry Ririn, terutama dalam hal kenyamanan ruang tunggu pelayanan dan juga memperhatikan setiap keluhan dari para pelanggan.

2. Laundry Ririn Palangka Raya, bisa memberikan jasa layanan antar jemput cucian, karena ini sangat dibutuhkan oleh para pelanggan yang memiliki aktivitas sibuk.

3. Dalam rangka meningkatkan citra perusahaan (jasa laundry Ririn), perlu adanya peningkatan lagi pada dimensi-dimensi pembentuk kualitas pelayanan karena dari semua dimensi pelayanan ini sangat mempengaruhi perkembangan usaha jasa laundry Ririn. 


\section{DAFTAR PUSTAKA}

Adrian, Payne, 2000, Pemasaran Jasa, The Essence of Service Marketing, Andi Yogyakarta.

Assauri, Sofjan. 2010. Manajemen Pemasaran: Dasar, Konsep \& Strategi. Jakarta: Raja Grafindo Persada.

Arifin, Zainal. 2014. Penelitian Pendidikan: Metode dan Paradigma Baru. Bandung: PT. Remaja Rosdakarya.

Astyasari Esti Mahanani. 2017, Skripsi, dalam penelitian yang berjudul "Persepsi Konsumen Terhadap Kualitas Produk dan Pelayanan di Rumah Makan Moro Sakeco Grabag Magelang".

Basrowi \& Suwandi. 2008. Memahami Penelitian Kualitatif. Jakarta: Rineka Cipta.

Bungin, Burhan. 2011. Penelitian Kualitatif. Jakarta: Kencana Perdana Media Group.

Daryanto. 2011. Manajemen Pemasaran: Sari Kuliah. Bandung: Satu Nusa.

Emzir. 2012. Metodologi Penelitian Pendidikan Kuantitatif dan Kualitatif. Bandung: Rajagrafindo Persada.

Lupiyoadi, Rambat. 2013. Manajemen Pemasaran Jasa (Edisi 3). Jakarta: Salemba Empat.

Keegan, Warren J. \& Mark. C. Green. 2013. Global Marketing. Harlow: Pearson.

Kotler. 2005, Manajemen Pemasaran, Prehalindo, Jakarta

Komar. R. 2006. Hotel Management-Manajemen Perhotelan, Grasindo, Jakarta.

Kotler. 2009, Prinsi-prinsip Pemasaran, Edisi 12, jilid 2, Jakarta: Erlangga

McDougall, Gordon H.G. \& Terrace J. Levesque, 2000. Customer Satisfaction With Services: Putting Perceived Value Into The Equation, Journal of Service Marketing, Vol. 14 No. 5, Hal. 392-410

Mowen, Jhon C. \& Michael Minor, 2002. Perilaku Konsumen, Jilid 1, Edisi Kelima. Jakarta: Penerbit Erlangga.

Murdifin Haming \& Mahfud Nurnajamuddin. 2012. Manajemen Produksi Moder, Edisi Kedua, buku 2 PT. Bumi Aksara. Jakarta.

Stanton, William J. 1993. Prinsip-prinsip Pemasaran. Jakarta: Erlangga

Sastradipoera, Komaruddin, 2003, Manajemen Marketing; Suatu Pendekatan Ramuan Marketing, Kappa Sigma, Bandung.

Sugiyono. 2007. Metode Penelitian Bisnis. Bandung: Alfabeta

Tjiptono, Fandy, 2006. Service Quality and Satisfaction, Cetakan Pertama, Yogyakarta: Penerbit Andi.

Tony Wijaya, 2011. Manajemen Kualitas Jasa, Cetakan ke-1, Kembangan-Jakarta Barat: PT. Indeks.

Yazid. 2008. Pemasaran Jasa Konsep dan Implementasi. Yogyakarta: Ekonisia.

Yuditia Dwi Pebriani, 2016, Skripsi, Judul Penelitian: Pengaruh Persepsi Konsumen Terhadap Keputusan Pembelian Produk Merek Pribadi (Studi pada Indomaret di Ratu Dibalau). 